\author{
Liudas Zdanavičius* \\ General Jonas Žemaitis Military Academy of Lithuania
}

\title{
Impact of the Global Financial Crisis on Russia's Foreign Economic Policy
}

This article examines how the global financial crisis has affected Russia's foreign economic policy. An assessment of the crisis on Russia's economy is given, as well as Moscow's undertakings to strengthen its position in the global economic system: aspirations to an take active part in the new global financial order making process, plans to create an international financial centre in Russia, and strengthening of economic integration between CIS countries.

\section{Introduction}

Russian leaders stress that the increased economic power has significantly improved the ability of this country to increase its influence on global processes. Moscow sees itself not just a passive observer of the international economic processes, but also as an active player in this field.

Therefore, the primary purpose of this article is to evaluate how these Moscow aspirations are affected by the global financial crisis. To start, an assessment of how this crisis affected the Russian economy and weakened its economic power is given. In addition, the article analyzes the means by which (in addition to manipulations with its major energy exporter status ${ }^{1}$ ) Moscow tries to increase its influence within on the global economic processes. The article is focused on the Kremlin's efforts to participate in the new global financial architecture creation process, create potent international financial centre in Russia and accelerate economic integration projects in the CIS.

Before beginning the analysis of Russian foreign economic policy, it is important to point out that it very controversial. At the same time, in the Kremlin's actions we can identify two main, often contradictory, directions:

- Realistic - neoimperial: the main aim of this direction is to recover for Russia the positions USSR had in the international political system

\footnotetext{
* Liudas Zdanavičius is a lecturer of the Political Science Department of the Military Academy of Lithuania. Address: Šilo 5A, LT-10322, Vilnius, Lithuania, tel. (+370 5) 2103569, e-mail: liudas.zdanavicius@gmail.com.

${ }^{1}$ While traditionally researchers, who analyze the economic component of Russian foreign policy, are focused on Moscow's actions in the field of export of energy resourses. This is because energy-related issues have very big importance in Russian foreign policy. However, it is worth to pay attention to other, often neglected aspects of Russian foreign economic policy.
} 
in the Cold war period. In order to achieve this goal, Russia seeks to maximize its power and to have maximal possible influence on both regional and global processes.

Such aims are clearly stated in the most recently published Russian strategic documents - "The Russian Federation Foreign Policy Concept" (made public in July, 2008) and "The National Security Strategy of the Russian Federation" (made public in July, 2009). These documents and public speeches of Russian leaders' show that Moscow continues to declare its allegiance to the vision of multi-polar world. A world where there are several strong centres of power (one of them, obviously, is Russia) is a much fairer and safer than the world dominated be the only one centre of power - the United States. Kremlin is annoyed by the NATO enlargement eastwards and expansion of Western countries influence in the "the traditional zone of Russia's interests" - CIS area $^{2}$.

The existing world economic order is perceived as unjust and serving only the developed Western countries, and particularly American, interests. Especially since the West has no interest to change the status quo. The Foreign Policy Concept of the Russian Federation unequivocally states, that "the West, realizing that it may lose the monopoly control of the globalization process tries to "withhold" Russia"3. The meaning of this statement is obvious - West, in Moscow's opinion, has no interest in the Russia's influence growth.

So as we can see in the official rhetoric of the Kremlin, Russia is shown as a victim of Western exploitation. In this case, Moscow's rhetoric is similar to the provisions of dependency theories on the unfair nature of the Global Capitalistic system and the need to transform this system to more effective and providing equal opportunities for all players.

- Neoliberal: in line with neoliberal ideology, which dominates global economic system, Russia positions itself as a state, "which plays under the general rules of the game". The main objective of this component of Kremlin's foreign economic policy is to achieve successful integration of Russia into the global economic system. The main means to achieve that - neoliberal domestic and foreign economic policy.

How to explain this phenomenon of the Russian foreign policy, when the Kremlin fights with "unfairness" of global economic system and at the same time declares loyalty for neoliberal "rules of the game", which in essence is the base for these unfair imbalances? Why are simultaneous acts of clearly neoliberal (accession to the WTO, tax reductions etc.) and non-liberal (such as strengthening of the state influence over the economy) carried out?

\footnotetext{
${ }^{2}$ Jellinek R., Russia and the global Meltdown: domestic and foreign policy responses to the international financial crisis, Moscow: Carnegie Endowment, 2009, p. 28-36.

${ }^{3}$ The Foreign Policy Concept of the Russian Federation, http://www.mid.ru/ns-osndoc.nsf/0e9272befa342 09743256c630042d1aa/cef95560654d4ca5c32574960036cddb, 20080712.
} 
First, this ambiguity could be explained by the hypothesis, that Russian leaders are not the heads of the strict pyramid of power, but just try to balance different interest groups in the country ruling elite. Therefore, domestic and foreign economic policy is based not on the thorough planned. Each action is just result of the interactions between competing interests in the ruling elite.

Among experts is popular the theory that in the Russian ruling elite there are two main competing forces - "siloviki" (power olligarchy), and "liberals" (sometimes called "civiliki" ${ }^{\prime \prime}$ ). One of the major differences in their opinions is - an approach to relations with the West ${ }^{5}$.

Russian policy in the financial field, is to a large extent carried out according to the strictest canons of neo-liberalism. Thus one can argue that it is dominated by liberals. Ministries of Finance and economy, the Central Bank and some other institutions are dominated by the strict followers of the monetarism ideas (according to George Soros terminology - market fundamentalists).

The dominance of neo-liberalism in Russia is largely determined by the historical circumstances. In 1992-1998 Russian economic policy was highly influenced by the representatives of the International Monetary Fund (IMF) and the World Bank. These organizations during the nineties strongly adhered to the "Washington Consensus" economic policy (neoliberal economic policy recipes, which should lead (at least theoretically) any country in the world to the success in the global economy), so the Russia was not an exception. This strongly influenced the Russian scientists and officials approach to the management of the economy.

Dominance of neo-liberalism in Russia can explained and from the viewpoint of the "dependency" theory. In this case, neo-liberal ideology is one of the ways through which the West is manipulating the peripheral economic policy. For example, the promotion of liberalization of the financial markets will open doors for expansion of the Western companies. It may be noted that both the Western media and international financial organizations (World Bank and IMF), even in times of crisis, welcome the neo-liberal component of the Russia's economic policy components.

However, it is clear that such a dominance of neoliberals could be easily removed by political will. So, such dominance is comfortable for the most of Russia's ruling elite members. It opens possibilities for "capital flight" abroad, corruption, etc. For example, financial reserves accumulated in 2004-2008 as a result of strict monetarian policy in 2008-2010 were used by the Kremlin to support the businesses of affiliated oligarchs.

Second, ambiguity of Russia's foreign economic policy can be understood as a planned action, which attempts to combine the most efficient components neoliberal and neoempiric rhetoric and actions. It is possible, that Russia tries

\footnotetext{
${ }^{4}$ Stratfor, The Kremlin Wars (Special Series), Part 3: Rise of the Civiliki, http://www.stratfor.com/memberships/147752/analysis/20091024_kremlin_wars_special_series_part_3_rise_civiliki, 20101024 .

${ }^{5}$ Tsygankov A., "Russia`s foreign policy" in Wegren S., Herspring D., eds., After Putin `s Russia: past imperfect, future uncertain. Lanham: Rowman \& Littlefield Publishers, 2010, p. 227-229.
} 
to use in the relations with the West at the same time and "the carrot" and "the stick".

It is likely that the Russian authorities understand that the possibilities to break the existing rules of the game have their limits. On the one hand Russia has limited resources, which are not enough, at least at this the moment, to become the dictator of the rules of the game in global economy. On the other hand, too much confrontation with the West could severely affect interests of the Russian companies and individual members of the ruling elite, which have broad ties with the Western countries.

The economic crisis has once again clearly demonstrated that Russia's economy is closely linked to processes, which are taking place on a global economic system.

\section{Impact of the Global Financial Crisis on the Russian Economy}

Before examining the Kremlin's foreign economic policy changes after the beginning of the global financial crisis, it is worth analyzing how this crisis has affected the Russian economy. Are trends of Russia's economic development favourable for Russia's aspirations to become one of the major centres of global power?

Russian leadership has repeatedly stressed that the country managed to overcome the economic turmoil, which followed the collapse of the Soviet Union. For example, the future president Dmitry Medvedev, in the beginning of 2007 with the pride declared that Russia in the near future will become one of the five largest economies in the world's on in terms of the size of the GDP.

From 1999 to the beginning of 2008 the Russian economy has demonstrated excellent growth. Every year GDP, industrial output, investment, population incomes has grown at the rapid pace. For example, the country's GDP during this period increased by 93 percent, while the nominal income of the population - more than 10 times (on the other hand, the annual inflation rate during this period was never less than 10 percent). The public external debt decreased by more than three-fold - from 153 billion U.S. dollars in 1999 up to 43 billion U.S. dollars in the October 2008. During the same period, Russia's foreign reserves increased from 11 to nearly 600 billion U.S. dollars ${ }^{7}$.

It should be noted that Russia's strong macroeconomic performance was not the result of the efficient economic policy, but the rapid growth of the oil and other raw material, which are the main Russia's export goods, prices. In the

\footnotetext{
${ }^{6}$ Reuters, Davos - Top Kremlin official Medvedev woos world forum, Jan 27, 2007, http://www.reuters.com/ article/idUSL2726905720070127, 13072010.

${ }^{7}$ Банк России, Внешний долг Российской Федерации в 2008 году, http://www.cbr.ru/statistics/print. aspx?file=credit_statistics/debt_currency_08.htm\&pid=svs\&sid=vdRFviv . [The Bank of Russia, Foreign debt of the Russian Federation in 2008] - in Russian.
} 
1997-1999, the average price of the Russian "Urals" brand of oil was between 9 and 20 dollars per barrel. In July, 2008 it exceeded the 140 U.S. dollars per barrel threshold for a short period of time ${ }^{8}$.

Country's successful economic development made its leadership to think that Russia will be not affected by the global financial crisis. In summer 2008 Medvedev and Putin have repeatedly stated that Russia is a quiet backwater bay in the ocean of the global economic crisis. This optimism is driven by the fact of the record high oil prices and the huge financial reserves, accumulated by Russia to that time.

However, in September 2008 it became evident that the economic crisis has badly hit "the silent bay". This influences by the three main factors:

First, in the global markets began a rapid decline of Russia's main export commodity prices. For example, the price of oil has fallen from a record 148 U.S. dollars per barrel in July, 2008 to the 35-40 U.S. dollars at the end of the same year. Prices of metals, fertilizers, timber, grain and some other commodities also declined sharply. This led to a significant drop of export incomes of the Russian companies and later this led to the decline of states tax revenues.

Second, the domestic and foreign investor began to "run" from Russia's financial markets. In 2008, almost 130 billion U.S. dollars were withdrawn from Russia9. It should be noted that in the 2004-2007 the direction of capital movement was opposite and "hot money" were flowing to the country's financial markets. Alone in 2007 more than 83 billion of U.S. dollars came to Russia as portfolio investment. Capital flight was ignited by the Russian - Georgian military conflict (the fear of a major Russian-Western relations degradation) and the fear of sharp Russian economic situation - deterioration - driven by a sudden drop in export commodity prices.

Third, the global financial crisis and fear of Western banks that fall of the commodity prices will significantly reduce the export revenues of Russian companies', and also drastically worsened borrowing conditions for the Russian companies and banks in the Western capital markets. The Russian foreign corporate debt in October 2008 exceeded 500 billion U.S. dollars ${ }^{10}$. A significant share of this debt was short term liabilities, for repayment of which it was necessary to obtain new loans. Therefore, serious risks for the country's biggest companies and banks (including governmental) bankruptcies has arisen.

The economic crisis in Russia began at the end of August 2008. The first signal was the stock market crash. Russia's RTS stock index fell from its maximum value in 2487 points in May, 2008 to less than 500 points in December,

\footnotetext{
${ }^{8}$ U.S. Energy Information Administration, World Crude Oil Prices, http://tonto.eia.doe.gov/dnav/pet/ pet_pri_wco_k_w.htm.

${ }_{9}^{9}$ Банк России, Платежный баланс Российской Федераиии за 2008 год, http://www.cbr.ru/statistics/ print.aspx?file=credit_statistics/bal_of_paym_an_08.htm\&pid=svs\&sid=pbDK_an . [The Bank of Russia, Balance of payments of the Russian Federation in 2008] - in Russian.

${ }^{10}$ Банк России, Внешний долг Российской Федерации в 2008 году, http://www.cbr.ru/statistics/print. aspx?file=credit_statistics/debt_08.htm\&pid=svs\&sid=vdR. [The Bank of Russia, Foreign debt of the Russian Federation in 2008] - in Russian.
} 
$2008^{11}$. Already in the fall of 2008 the country's banks and companies faced serious financial problems and were saved from bankruptcy only by urgent intervention of the government and the Central bank.

In October 2008 the crisis reached the country's so-called "real sector" (industry, trade, transport, agriculture and other non-financial economic sectors). A sharp decrease of industrial output, freight amounts, and retail turnovers began. This was followed by the sharp increase in the unemployment figures. According to official data, GDP in 2009 compared with 2008, decreased 7.9 percent. Industrial output decreased by 10.7 percent $^{12}$.

The fact that the economic consequences of the crisis in Russia were one of the deepest among the G-20 countries was in part the result of a failure of the government and the central bank's anti-crisis policy. While the huge funds were spent on anti-crisis measures, the biggest part of this expenditure went to the country's largest banks, public companies and oligarchs affiliated with the Russia's ruling elite. A good example of such inefficiencies was the decision to proceed with the gradual devaluation of the national currency. In the winter 2008-2009 of the ruble exchange rate against the U.S. dollar has been gradually reduced from 24 to more than 36 rubles per U.S. dollar. Meanwhile, as the devaluation was carried out gradually, from that process benefited the commercial banks close to the government, which earned between 30 and 60 billion of U.S. dollars. On the other hand, the Central bank lost on third of its foreign currency reserves (around 200 from nearly 600 billion of U.S. dollars).

Russia's economy was saved from total collapse by the fact that in spring 2009 oil and other export commodities prices began to grow. Till the beginning of 2010 oil prices reached 70-80 U.S. dollars per barrel. Similar oil prices were found in 2007 when Russia's economy has boomed.

An increase of oil and other commodity prices helped the Russian government to stop the decline of foreign reserves and increase revenues for the national budget. From the spring 2009 till the end of the same year, the ruble exchange rate grew from 36 to less than 30 rubles per U.S. dollar. Stock Exchange index RTS has grown from 500 points in the end of 2008 till 1534 points in March $2010^{13}$.

These indicators and the slowdown of country's economic decline encouraged Russia's officials to declare that the economic crisis is over. This position is supported by the IMF and the World Bank, whose forecasts predicts that in 2010 Russia's GDP will begin to grow again ${ }^{14}$.

\footnotetext{
${ }^{11}$ РБК, Индекс РТС, http://stock.rbc.ru/demo/rts.1/daily/RTSI.rus.shtml?show=2Y . [RBC, Russian Trading System Stock Exchange index] - in Russian.

${ }^{12}$ Федеральная служба государственной статистики, Основные статистические показатели, http://www. $\mathrm{gks.ru} / \mathrm{wps} / \mathrm{portal} /$ /.ut/p/.cmd/ces/.exp/7_0_86J/.miid/null/.exps/true/.def/false/.scr/Home/_s.7_0_A/7_0_8QL/ th/J_0_LV/_s.7_0_A/7_0_8QL/me/7_0_86N-7_0_7UL-7_0_7UJ-7_0_A\#7_0_86J [The Federal State Statistics Service of the Russian Federation, Basic statistical indicators]-in Russian.

${ }^{13}$ РБК, Индекс РТC, http://stock.rbc.ru/demo/rts.1/daily/RTSI.rus.shtml?show=2Y. РБК, Индекс РТС, http://stock.rbc.ru/demo/rts.1/daily/RTSI.rus.shtml?show=2Y [RBC, Russian Trading System Stock Exchange index] - in Russian.

${ }^{14}$ International Monetary Fund, World Economic Outlook (WEO) Sustaining the Recovery, http://www.imf. org/external/pubs/ft/weo/2009/02/index.htm.
} 
However, both opponents of the government (for example, M. Delyagin, V. Milov, N. Kritchevsky etc..) and some officials (for example, Minister of finances A. Kudrin, and CEO of the state owned bank Sberbank G. Gref) believe that Russia may face a second wave of the crisis. It may be induced by the following factors:

- Despite some good dynamics in the economic development of Russia, financial situation of most banks is quite difficult. Rapid growth of so called "bad loans" could lead to the wave of bank bankruptcies. In such case a situation could be stabilized only by rapid governmental intervention.

- Difficult situations in the public finances and the pension system. The Russian government in the expectation that the crisis will be short-term, decided not to reduce budget spending. Difficult budget situation (the deficit for 2009 was 6 percent. GDP in 2010 projected 6.7 percent of $\mathrm{GDP}^{15}$ ) is exacerbated by the decision to significantly raise the size of the old-age pensions. The budget deficit is financed from financial reserved accumulated in the period of high oil prices. The Finance Ministry estimates suggest that if the current level of budget expenditures will be preserved, Russia's reserve fund, from which budget deficit is financed, will be exhausted in 2011.

The long-term economic outlook for Russia is even grimmer. The economic crisis has demonstrated that Putin's reign, despite the huge increase in oil and other commodities export revenues, thus failed to resolve the country's fundamental economic problems. Good macro-economic indicators only hid core structural problems of the Russian economy. Economic crisis again raised them to the surface.

These fundamental problems of the Russian economy should be identified:

- Dependence on raw materials (especially oil and gas) exports. Although country leaders from the moment when V. Putin came to power in 1999 constantly talking about the need to reduce the country's economic dependence of Russia also failed to reach this goal. By contrast, share of oil, gas and other energy resources in the total export rose from 54 percent in 2000 to 66.7 percent in $2009^{16}$.

- This implies that Russia, despite ambitions to be one of the world's

\footnotetext{
${ }^{15}$ Федеральная служба государственной статистики, Социально-экономическое положение России, http://www.gks.ru/wps/PA_1_0_S5/Documents/jsp/Detail_default.jsp?category=1112178611292\&elem entId=1140086922125 [The Federal State Statistics Service of the Russian Federation, Socio-economic situation of Russia] - in Russian.

${ }^{16}$ Федеральная служба государственной статистики, Внешняя торговля Российской Федерации (по данным таможенной статистики), http://www.gks.ru/wps/portal/!ut/p/.cmd/ces/.exp/7 0 8F4/.miid/

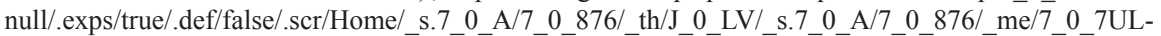
7_0_7UJ-7_0_A\# [The Federal State Statistics Service of the Russian Federation, Foreign trade of Russian Federation (custom statistics)] - in Russian.
} 
economic leaders, has to settle with the status of a raw material supplier for the West and China. Dependence on oil and gas exports makes Russia highly dependent on price fluctuations of these commodities in the world market. Moreover, even at high prices, revenue from energy and other raw materials export is not enough to ensure a high standard of living for the majority of the population.

- Especially since the future outlook for the energy and raw materials export is not very favourable for Russia. On the one hand, the breakthrough in shale gas extraction technologies has significantly increased the supply of natural gas in the U.S. market. This has led to a fall in natural gas spot prices in the markets of Western countries. It is likely that after beginning of active exploitation of the shale gas fields the slate of in the EU, Ukrainea and China outlook for Gazprom's exports could be very grim ${ }^{17}$. On the other hand, it is not clear whether Russian energy companies will be able to avoid a major fall in oil and gas production volumes, which could result from currently exhaustion of currently operated fields and inadequate investment in new mining projects.

- It should be noted that the economic crisis has only further aggravated the situation of the Russian industry, producing high value-added products. Even the last significant remnant of the Russian high-tech sectors - defence industry - is experiencing not the best times, despite constant growth of government spending on weapons acquisition. In the near future Russia may lose the capability to produce most of hightech weaponry and will be forced to rely on weapon import.

- Even worse is the situation of science. In 2008 the Russian economy used 2.5 times less homemade technologies than in 2000. Between 1992 and 2008 share of Russian patents in the total number of patents issued worldwide declined from 4.6 to 2.6 percent ${ }^{18}$.

- Worn out infrastructure and production facilities. In 2000-2008, despite tremendous revenues from exports, the Russian economy continued to suffer shortages of investment in infrastructure, industrial equipment and other fixed assets. For example, more than half of the railways were first built before 1916, housing and utilities funds are worn more than 70 percent. In some industries, up to 90 percent of equipment is worn out. So actually Russian economy functions using Soviet era legacy (heritage?). Some experts stress that the moment is coming at the fast pace, when the Soviet era assets will perish en masse and Russia will face a number of technogenic catastrophes, which consequences could be difficult to solve even using a huge investments. It is likely that the major accident in Sayano-Shushenskaya Dam certainly will not be the last such disaster.

- Demographic problems. The Russian population in 2001-2009 decreased

\footnotetext{
${ }^{17}$ The fall of demand for natural gas and uncertain prospects for its growthe in the future Gazprom was forced to postpone the Shtokman gas field development works.

${ }^{18}$ Иноземцев В., "Modernizatsya.ru: Что осталось на трубе", Ведомости, 200905 05. [Inozemtsev V., "Modernizatsya.ru: What is left on the pipe", Vedomosti, 200905 05] - in Russian.
} 
from 146.3 to 141.9 millions $^{19}$. Also there is an acute problem of population aging, which already in the short term can lead to pension system crisis.

- Corruption and poor quality of public administration. The extent of corruption in Russia is very well illustrated by the fact that this country's corruption rankings, annually published by Transparency International, are in pair with African countries. National Anti-Corruption Committee (NGOs engaged in the fight against corruption) research shows that the annual turnover of "corruption market" is between 240 and 300 billion U.S. dollars, which represents more than 25 percent of country's GDP (for comparison - the same turnover in China is around 80 billion U.S. dollars $)^{20}$.

Inefficiencies of public administration were still further accentuated by the economic crisis, when quick decisions were taken only in the cases, when it was necessary for oligarchic business structures or public corporations. At the same time, the Government has responded very slowly to the crisis in the "real sector" and the majority of anti-crisis measures were inefficient because of poor control of use of funds ${ }^{21}$.

Russian authorities are aware of these root problems. During economic crisis country's economic modernization was named a key priority. For example, in November 2009, in his annual address for the Federal Assembly, president Medvedev declared that one of the major goals of Russia's relations with foreign countries is the modernization of the Russian economy. Therefore, foreign policy must be the very pragmatic and the basic criteria of its success - whether this policy improves living standards in Russia.

Russian leaders declare that successful modernization will help to create many highly competitive sectors in the (not just raw materials) economy, based on innovations. This would substantially increase Russia's capacity to influence global economic processes.

However, it is very doubtful that Russia's leaders will be able to successfully implement their modernization plan. Any serious modernization measures will encounter fierce resistance from the interest groups in the ruling elite. On the other hand, modernization is promoted by the fear of Russia's leaders that otherwise the country's economy will collapse. In that case they

\footnotetext{
${ }^{19}$ Федеральная служба государственной статистики, Численность населения, http://www.gks.ru/ free_doc/new_site/population/demo/demo11.htm [The Federal State Statistics Service of the Russian Federation, Size of the population] - in Russian.

${ }^{20}$ Grani. ru, Объем коррупчии в России достиг четверти ВВП, 200903 17, http://www.grani.ru/Politics/ Russia/m.148724.html [Grani.ru, Share of corruption turnover in Russia reached quarter of GDP, 2009 03 17] - in Russian.

${ }^{21}$ High levels of corruption and general inefficiency of public administration implies that despite the low energy and labor prices in Russia to build a kilowatt of electrical power costs 40 percent more than in Germany; to build a square. meter of commercial storage facilities in Moscow - 3 to 3.5 times more expensive than in Paris or Rome, and one kilometer of motorway construction is 3-4 times more expensive in Russia than average in EU countries.
} 
will lose the power. Thus one can expect that the worse will be the country's economic situation (for example, number of technogenic catastrophes will increase etc.), the stronger motivation Russian leaders will have to actually carry out the country's economic modernization.

So, to sum up the possibility for Russia to become a major player in the global economy could be assessed ambiguously:

On the one hand, by the nominal size of GDP this country is among the seven largest world economies. In addition, growing global concerns about the potential shortages of energy resources, raw materials and food, are of heightened importance to Russia as the country has plenty of such resources.

On the other hand, Russia's economy is hard hit by the global financial crisis and rapid recovery could be expected in case if export commodity prices in the world market will reach record heights of 2007-2008. However, if Russia will not succeed in solving its deep economic problems, it may be necessary for the Kremlin to take care not to how to on how to avoid domestic economic disaster instead of achievement of its ambitious global goals ${ }^{22}$.

\section{Russia's Foreign Economic Policy during the Global Financial Crisis}

\subsection{Russian Efforts to use its Foreign Currency Reserves to Increase Influence on the International Economic System}

As already mentioned, the Russian economic situation at the beginning of the global financial crisis was very good. Its public foreign debt was minimal, and Kremlin had third world's largest foreign exchange reserves on its disposal (in August 2008 their amount reached 600 billion U.S. dollars, until the end of February 2010 they had shrunk to 439 billion U.S. dollars ${ }^{23}$ ).

During the crisis, when many countries suffer from the debt burden, Moscow was trying to use its foreign exchange reserves to increase its influence.

Prior to the analysis of how Moscow seeks to use its currency reserves, it is necessary to discuss the ambiguous situation with accumulation of foreign exchange reserves in Russia.

A significant part of the Russian foreign reserves consists of sovereign funds. Since 2004, Russian leadership has decided to accumulate large share of the revenues generated by the oil exports into a so-called stabilization fund. In 2008 the fund was divided into two new funds - the Reserve fund (it is intended

\footnotetext{
${ }^{22}$ This position is shared by U.S. Vice President Joe Biden, predicted in summer 2009 that the economic and social problems will force Russia to once again improve its relations with the West. See.: Spiegel P., "Biden Says Russia Will Bend Weakened the U.S.", Wall Street Journal, 200907 25,

${ }^{23}$ Банк России, Международные резервы Российской Федераиии, http://www.cbr.ru/hd base/mrrf/?C mes $=01 \&$ C year $=2010 \&$ To $\_$mes $=03 \&$ To $\_$year $=2010 \& x=29 \& y=11 \&$ mode $=[$ The Bank of Russia, Foreign exchange reserves of Russian Federation] - in Russian.
} 
to cover the budget deficit during the periods of crisis) and the National Wealth Fund (the money from this fund could be used to cover pension system deficits and other purposes). In December 2009 the size of the Reserve fund was 75 billion U.S. dollars and of the National wealth fund - 93 billion U.S. dollars ${ }^{24}$.

The money of the sovereign funds are invested into the safe financial instruments abroad. It should be noted that the accumulation of such sovereign funds is promoted and implemented by the neo-liberals in Russia's government (Minister of finance A. Kudrin, Central Bank Chairman S. Ignatiev, and others). For the creation of these funds the following arguments were used:

- To combat inflation, it is necessary to restrict the supply of money in the economy, so the sterilization (investment abroad) of the "excessive revenues" is needed ${ }^{25}$.

- The fund accumulated reserves "for a rainy day", for a situation when the prices of oil on the world markets fall sharply. It should be noted that this logic worked well in 2008-2009, when the money from sovereign funds were used to stabilize a situation in the Russia's financial system.

- The funds were invested abroad for several reasons: First, Russia's financial system was underdeveloped, and therefore, it could not offer a reliable and efficient financial instrument for such big investments. Second, investment of sovereign funds abroad is a global practice: for example, Singapore, Norway, China, and Japan behave in the same way. Thirdly, in such way funds are protected from misuse.

It should be noted that the fact that such funds were created and significant amounts of reserves accumulated is an evidence of a huge influence of neo-liberals on the country's economic policies.

At the same time Russian economist S. Glaziev identifies the main discrepancy of such policy. Although the Kremlin often declares the confrontational stance towards the West, at the same time the Russian state's funds are invested in the economies of the Western countries. This comes at a time when the Russian economy persistently lacks investments. Russian companies and banks are forced to borrow abroad and to pay much higher interest rates than the Russian state receives from its investments abroad ${ }^{26}$. It is interesting to note the fact that the total foreign debt Russian companies and banks never exceeded the total amount of Russian foreign reserves. Therefore, people in

\footnotetext{
${ }^{24}$ Министерство финансов Российской Федерации, Совокупный объем средств Фонда национального благосостояния, http://www1.minfin.ru/ru/nationalwealthfund/statistics/volume/index.php?id4=6412 . [The Ministry of finance of the Russian Federation, The National wealth fund] - in Russian. From June 2010 information about size of both funds is classified.

${ }^{25}$ It should be noted, that despite these measures the government failed to contain inflation, because the main reason of inflation in Russia is not the excessive money supply, but the dominance of monopolies in the economy.

26 Эхо Москвы, Интервью С.Глазьева, 200810 16, http://www.echo.msk.ru/programs/razvorot/547077echo/ [Radio station "Echo Moskvy", Interview of S. Glaziev, 200810 16] - in Russian.
} 
charge of Russia's economic policy are often accused of conducting pro-western (especially pro-U.S.) policy.

However, during the global economic crisis it has become clear that Russia may use its financial reserves, not only for economic, but also for political goals: In this area, duality of Russia's foreign economic policy should be clearly identified:

From the very beginning of the crisis, Moscow declared that it will do everything possible to ensure global financial stability. One of the measures to achieve this goal was responsible investment of its foreign reserves.

A good example of this policy was Russia's decision to support U.S. federal mortgage agencies, which have become one of the first victims of the global financial crisis. The first indicators of the extensive problem in the U.S. mortgage market were visible in the middle of 2006. In 2007 a large-scale crisis in this sector had began. However, Russia continued to actively increase its lending volume to U.S. mortgage agencies, which were particularly hardly hit by the crisis. Moscow did not stop, even with the fact that in fall of 2007 the share prices of these agencies fell by more than one third. The total Russian foreign reserves and fund investments in U.S. government mortgage agencies Fannie Mae and Freddie Mac bonds at the end of 2007 reached more than 100 billion U.S. dollars. In January 2008 Russian Ministry of Finance issued a decree, which once again included bonds of these agencies to the list of high priority investment instruments for a Russian foreign reserve funds ${ }^{27}$.

These investments were only suspended in the spring 2008, when both agencies found itself on the verge of the bankruptcy. During 2008, the amount of Russia's foreign reserves invested in U.S. government mortgage companies Freddie Mac and Fannie Mae decreased 25-fold (from 103 to 4 billion. U.S. dollars $)^{28}$.

It should be noted that substantial amounts of funds from mortgage agencies bonds were invested into U.S. Treasury bonds. During 2008, investments into U.S. Treasury bonds increased 3.5 times. Thus, Russia's reserves are still invested in the U.S. economy and the dollar zone. In the fall of 2009 about 30 percent of Russian foreign reserves were invested into U.S. treasury bonds. Russia holds seventh place by the size of such investments. In September 2009 Russia had acquired these bonds for the total amount of 121 billion. U.S. dollars, which represents 4.26 percent of released in the U.S. treasury bonds (this list is headed by the China - 799 billion U.S. dollars (23 percent.) $)^{29}$.

Such Russian behaviour can be interpreted by the following pragmatic reasons:

\footnotetext{
27 “ЦБ и Минфин заработали на американской ипотеке”, РБК-Daily, 200808 21, http://www.rbcdaily.ru/2008/08/21/finance/371867 [The Central bank and Ministry of finance made profit on the American mortgages, RBC-Daily, 200808 21] - in Russian.

${ }^{28} \mathrm{Ibid}$.

${ }^{29}$ U.S. Treasury department, Major foreign holders of Treasury securities, http://www.treas.gov/tic/mfh. txt, 20100713.
} 
- Russia's Central Bank officials state that investment in the U.S. mortgage agencies bonds were profitable and were made because these securities had the highest ratings. In addition, these financial instruments due to their high reliability were acquired by many other countries.

- Russia increased its prestige, by showing itself as a responsible player, actively engaged in ensuring the stability of the international economy.

- The bankruptcy of the U.S. mortgage agencies could hardly hit the international economy and that would be useless for Russia itself. In addition, this could lead to depreciation of Russia's foreign reserves.

- It is possible that there was an informal agreement between Washington and Moscow on this issue.

At the same time Russian investments could be seen as a tool to influence U.S. policy. The United States suffers from its huge public debt and is dependent on the possibilities to successfully sell its Treasury bonds. Therefore, the threat to withdraw the funds from U.S. Treasury bonds may be an effective way to make pressure on Washington.

In 2008-2009 Russia had tried to use this as a weapon. The former U.S. Treasury Secretary Henry Paulson said in his book of memoirs that in 2008 August, Russia has tried to persuade China to jointly sell U.S. mortgage agency bonds, thus creating serious difficulties for the U.S. economy ${ }^{30}$.

Such actions included intimidations by the Russian officials to change Russia's foreign exchange reserves investment instruments. For example, the Russian Central Bank Deputy Head A. Uliukaev, in June 2009, said that Russia plans to transfer some funds invested in U.S. treasury bonds to other investment instruments, in particular, the IMF bonds. The Minister of Finance A. Kudrin announced that Russia plans to buy IMF bonds for 10 billion U.S. dollars. The news about Russia's plans to reduce lending to the U.S. government led to a significant extent, but the short-term depreciation of U.S. dollar against other major currencies ${ }^{31}$.

However it should be noted, that Moscow's possibilities to press the United States using its investments in Treasury bonds are very limited, because Russia's share in the U.S. Treasury bonds, in contrast to China, which quite successfully uses this as a pressure, is insignificant.

On the other hand, the Kremlin's possibilities to use its foreign reserves as the tool of influence were increased by the fact that Russia's state had no need to borrow abroad. However, it is now clear that the depletion of government financial reserves will change Russia's position from the lender to the debtor.

In 2009 it was announced that the Russian state is planning to resume borrowing in foreign markets. It will start after a long break (the last time Russia

\footnotetext{
${ }^{30}$ Bloomberg, Paulson Says Russia Urged China to Dump Fannie, Freddie Bonds, 20100129.

${ }^{31}$ Bloomberg, Russia May Swap Some U.S. Treasuries for IMF Debt, 20090610.
} 
borrowed abroad before the economic crisis of August 1998). In 2010 Ministry of finance plans to sell euro-bonds for 17.8 billion. U.S. dollars and borrow 2-4 billion U.S. dollars from the World Bank ${ }^{32}$. In total over the next three years, Russia plans to borrow abroad more than 60 billion U.S. dollars.

\subsection{Russia Aims to Influence the Transformation of the Global Financial System}

Since the beginning of global financial crisis, Russia is actively advocating for the need to reform the current global financial order because it has major structural deficiencies. In January 2009 in the Davos World Economic Forum Russian Prime Minister V. Putin said that the current global economic system crashed and its reformation is inevitable ${ }^{33}$.

Russia's proposals on reforming the international economic system have been made public before the London G-20 Summit in March 2009 (before it was possible to record only the individual submissions of the Russian leadership on this issue). Among the major proposals can be distinguished:

- Strengthening of the international financial markets regulation.

- The need to develop and adopt an internationally agreed upon standard in the field of macroeconomic and budgetary policies, which would be mandatory for leading global economies, including countries issuing reserve currencies.

- Enlargement (diversification) of the list of currencies used as reserve ones.

- Introduction of a supra-national reserve currency to be issued by international financial institutions. This currency could be created on the basis of IMF SDRs.

- Promotion of the development of major regional financial centres, existence of which could reduce volatility of global financial system.

- IMF should be reformed and its competences expanded. In order to overcome the current crisis, resources of this organization should be significantly increased ${ }^{34}$. It should be noted that for a long time Russia has been advocating the reforms of the IMF, which would significantly increase quotas of the emerging economic powers. In Moscow's

\footnotetext{
${ }^{32}$ Пресс-служба Минфина России, Интервью Д.В. Панкина инфомационному агентству “Рейтер”, http://www.minfin.ru/ru/press/speech/index.php?id4=7910 [Press Service of the Russian Ministry of Finance, Interview of Pankin D.V. to the news agency Reuters] - in Russian.

${ }^{33}$ РИА НОВОСТИ, Доклад Владимира Путина в Давосе. Полная версия, 200901 29, http://www.rian. $\mathrm{ru} /$ economy/20090129/160410501.html [RIA Novosti, The speech of Vladimir Putin in Davo. Full version, $20090129]$ - in Russian.

${ }^{34}$ Администрация Президента Российской Федерации, Предложения Российской Федерации к саммиту “Группы двадиати” в Лондоне (апрель 2009 года), 200903 16, http://tours.kremlin.ru/text/ docs/2009/03/213992.shtml [The Office of the President of the Russian Federation, Proposals to the G20 Summit in London (April 2010), 200903 16] - in Russian.
} 
opinion, the current management system of this organization does not reflect the changed world economic structure. In this context, Russia demonstrated itself as selfless campaigner against injustice, as the reform of the IMF itself should not significantly increase Russia's influence over the organization's decisions.

It is clear that the aim of the majority of Russia's proposals is the reduction of the influence of the United States and other Western countries on the international economy.

Moscow blamed irresponsible U.S. and other Western economic policies for the crisis induction. Russian President D. Medvedev in his speech during St. Petersburg Economic Forum in June 2009 stated that the unipolar world system and artificially maintained monopolies in the key sectors of the global economy are the fundamental cause of the crisis ${ }^{35}$.

Russia perceives the United States as a country benefiting from the dollar as the world's main reserve currency status. In Moscow's opinion, the wellbeing of the United States to a large extent is based on the exploitation of other countries (including Russia). During the economic crisis Russia, like other countries, continues to suffer from irresponsible U.S. fiscal policies.

It should be noted that Moscow's bold proposals for introduction of new supranational reserve currency instead of the U.S. dollar did not achieve the approval of the other G-20 members. In principle, such types of proposals were not even seriously discussed during the G-20 meetings. World leaders and the media pay much more attention to China's proposals in this field. Russia is generally not regarded as an authoritative state, which can have a significant impact on the international economic system reform process.

In Moscow's view, this is because the U.S. and the West are in general against the substantial changes of existing status quo in the global financial system. Necessary reforms would destroy the Western monopoly on the most important decisions related to the management of international economic system.

In order to strengthen its influence in the process of international financial system reformation Russia is seeking new allies.

In June 2009 the first official meeting of non-formal club of emerging economies BRIC (Brazil, Russia, India and China), initiated by Russia, was held. It is obvious that after a failure to gain a sizable impact on the G-8 or G-20 level, Moscow aims to consolidate the BRIC countries in opposing U.S. hegemony in the global economic system. It is clear that Russia sees itself as a leader of such a consolidated fight. However, the results of the meeting showed that the other BRIC countries have not tended to support the aspirations of Russia.

On one hand, at the meeting, the representatives of BRIC countries stressed necessity for the formation of a better functioning and more diversified glo-

\footnotetext{
${ }^{35}$ Петербургский международный экономический форум, Стенографический отчет, 200906 05, http:// www.forumspb.com/upfile/file2/june_5_plenary_rus.pdf [St. Petersburg International Economic Forum, Stenographic report, 200906 25] - in Russian.
} 
bal financial system. On the other hand, the BRIC states did not support Russia's bid to create a supranational international reserve currency as a counterweight to the U.S. dollar. At the meeting Russia also proposed an agreement between the BRIC countries to move towards a broader use of national currencies of each others. However, it was agreed that the next meeting of BRIC will discuss possible guidelines for reforming the IMF, so that this organization to better reflect changes in the structure of the international economy (in particular, the increased economic weight of the BRIC countries).

In addition, President Medvedev's economic adviser Arkady Dvorkovitch in June 2009 said that Russia is considering the possibility of transferring part of their reserves from a dollar denominated securities to the government bonds of the BRIC countries. Admittedly, this could happen only if the BRIC would invest their money into the Russian government bonds.

To sum it up, Russian attempts to influence the global financial systems transformation process as of this moment are fruitless. While Moscow's proposals in many aspects is similar to some other countries (notably the BRIC states) interests, Russia clearly does not have sufficient economic weight and credibility to make its voice heard and seriously taken into account.

\subsection{Attempts to Create International Financial Center in Russia}

According to Russian leaders this country will become one of the new poles of economic power in the new world economic order, which will appear after the end of global financial crisis. For that purpose Russia tries to become an international financial centre.

In May 2008, the Russian Ministry of Economic Development announced an international financial centre in Russia as part of the development program. In summer 2009, the Government approved the plan for basic steps to develop an international financial system. In December 2009 a new concept for the creation of an international financial centre in Russia was made public. This document states that if the Russian government's actions in this field are successful then the following main objectives will be achieved:

- The ruble will become one of the international reserve currencies (in conjunction with the U.S. dollar, euro, etc.).

- A ruble will be used in a considerable share of Russian foreign trade operations.

- Russia's stock markets will become one of world's most important trading places for securities, raw materials and other items. ${ }^{36}$

However, success of these ambitious Moscow goals appear to be quite questionable:

\footnotetext{
${ }^{36}$ Министерство экономического развития Российской Федерации, Конщепџия создания международного финансового иентра в Российской Федераиии. Проект, 200912 30, http://www.economy.gov.ru/minec/ activity/sections/finances/creation/conceptmfc [The ministry of economic development of Russian Federation, The Concept of creation of international financial center in Russia, The project, 2009 12 30] - in Russian.
} 
First, Russia is not very successful in creation of business climate, characterized by low levels of corruption, property rights protection, transparency and other properties attractive to foreign investors. It is clear that events such as the Yukos case, Shell and Gazprom conflict on Sakhalin-2 Project, does not improve Russia's attractiveness in the eyes of investors.

Secondly, an international financial centre must be based a well developed economy, based on the strong economic performance. As already mentioned, the Russian economy is hardly hit by the economic crisis and its future prospects are uncertain.

Despite that, the Kremlin is taking active steps in order to achieve this ambitious goal. The biggest activity could be seen in the field of the introduction of a broader use of the ruble in the foreign trade operations.

The Russian ruble is now a peripheral currency, which is used in only 0.16 percent of world transactions turnover. Most of the Russia's foreign trade is also nominated in U.S. dollars and Euros.

Broader use of the ruble would allow them to achieve several goals. Foreign banks and the companies would be forced to accumulate ruble reserves, as they would be required for foreign trade operations with Russia. In addition, it would reduce the dependence on the U.S. dollar and the euro, and accordingly on the economic policy of the Western countries.

Already in 2006, Vladimir Putin called Russian companies to sell oil and gas to foreign markets in rubles. In November 2008 in its first Address to Federal Assembly president Medvedev said that a broader use of ruble in foreign trade is a priority goal of the Russia's foreign economic policy ${ }^{37}$.

In 2008-2010 this measures were taken to introduce broader usage of the ruble:

- Russia offers to foreign countries to sign international agreements, which would allow broader use of ruble in bilateral trade. Most foreign partners met such proposals with scepticism. Better results in the expansion of ruble have been achieved only in CIS area. In 2009, trade operations in rubles represented more than half of the whole commercial transactions turnover between Russia, Kazakhstan and Belarus (the U.S. dollar accounted for less than one-third) ${ }^{38}$.

- In order to increase the importance of the ruble, Russia offers CIS countries loans in rubles. It should be noted that the CIS countries are sceptical about the possibility of obtaining credits from Russia in rubles instead of Euros or U.S. dollars.

- In order to carry out trade of petroleum, grain, fertilizers, sugar and other raw materials in rubles in 2008 St. Petersburg Stock Exchange

\footnotetext{
${ }^{37}$ Послание Федеральному Собранию Российской Федерации, 200811 05, http://www.kremlin.ru/ appears/2008/11/05/1349_type63372type63374type63381type82634_208749.shtml [Address to Federal Assembly of the Russian Federation, 200811 05] - in Russian.

38 Голос России, Сергей Глазьев: Ни один из участников Таможенного союза не может вести переговоры отдельно, 200912 02, http://rus.ruvr.ru/2009/12/02/2480068.html [Voice of Russia, Glaziev S., None of the participants of the Customs Union can not negotiate separately, 200912 02] - in Russian.
} 
was opened (the opening process for various reasons, lasted more than three years). In 2009 possibility to trade its oil in this stock exchange was offered to Iran. Tehran despite its declarations about intentions to abandon U.S. dollar in its oil export operations, met Russian proposal with caution ${ }^{39}$.

- In September 2008, in St. Petersburg, was opened another - the natural gas exchange, where natural gas is sold for rubles. It is planned that after the completion of "Nord Stream" pipeline the customers from Western Europe will be able to buy at this exchange a large part of the necessary quantities of gas, which will be then supplied through this pipeline. However, in this case, the main reasons for opening stocks are Gazprom's aims to sell natural gas to consumers within Russia for the highest possible price ${ }^{40}$.

Despite the declarations, the Russian government is quite unsuccessful in its aims to increase ruble usage in the foreign trade. This happens due the following fundamental reasons:

Firstly, the attractiveness of ruble is reduced by the instability of the exchange rate of this currency. In addition, companies and investors cannot rely on the Russian government officials' declarations about ruble exchange rate. For example in autumn - winter of 2008, Russian leaders reiterated that the ruble will not depreciate. Those declarations kept coming even when deep ruble devaluation began.

Secondly, Russian businesses, are not interested in the usage of ruble in its commercial operations. So far, the Russian leadership cannot force even public companies sell exported oil and natural gas for rubles. The reason is that even if in trade operations rubles will be used, oil prices are still tied to the U.S. dollar, whereas the ruble does not have any significant positions in the global financial system. Since the ruble exchange rate to U.S. dollar is not stable Russian oil customers will pay lower prices for Russian exporters in order to hedge against currency risk.

Gazprom is not interested to switch to rubles because in this case the company would be forced to revise its long-term contracts with European customers and possibly provide additional advantages for them.

Thirdly, in switch to rubles are not interested foreign customers of foreign buyers of Russian raw materials.

Fourth, the majority of Russian oil is not sold directly to its customers, but instead to companies-mediators. It is likely that in many cases, these agents are so closely linked with the top management of energy companies and the

\footnotetext{
39 Зыков С., "Нефть в обмен на рубли: Ирану предложено торговать “черным золотом” на Петербургской бирже”, Российская газета, 200903 04. [Zykov S., Oil in exchange for rubles: Iran got the proposal to trade it "black gold" on the St. Petersburg exchange", 200903 04] - in Russian.

${ }^{40}$ Fintimes.ru, Превратить постсоветское пространство в рублевое!, 200906 03, http://fintimes. km.ru/aktualnye-temy/7672 [Fintimes.ru, To turn post-soviet space in the ruble space!, 200906 03] - in Russian.
} 
members of the Russian ruling elite. Foreign trade operations are often used as a tool for "capital flight" from Russia or the part of corruption "schemes" It is obvious that switching to rubles could create additional obstacles for such operations.

In conclusion, although Moscow has managed to expand the ruble use in the CIS, success prospects for creation of an international financial centre still seem pretty vague. This goal could be achieved only with substantial improvements in the investment climate in the country, ensuring a successful long term economic development and breaking exporting companies opposition.

\subsection{Promotion of Economic Integration between CIS Countries}

During the economic crisis, Russia has stepped up its activities in promotion of the economic integration project in CIS. It is obvious that if the successful and effective economic integration project would be created, Russia naturally becomes its leader. That success would naturally strengthen Moscow's position as a global economic power centre.

The economic crisis has increased the opportunities for Russia to influence its neighbours in the CIS space. Russia, although faced with serious economic problems, is in much better economic shape than many other countries in this zone (except for Azerbaijan and Kazakhstan). At a time when most states of the CIS suffer from foreign debt burden, Russia has accumulated significant foreign exchange reserves.

In addition, the economic crisis in Russia adversely affected by its neighbours in the CIS. A result of increased protectionism and reduction of demand is the reduced opportunities to export their products to Russia. Another pressing problem was the deterioration of the situation of labour migrants in Russia. Problems in the construction sector and rising unemployment among Russian citizens negatively affected incomes of labour migrant. This causes a negative impact on some CIS countries. For example, the World Bank estimates that the labour migrant remittances in 2007 accounted for 36 percent of Tajikistan and Moldova's GDP, 27 percent of Kyrgyzstan GDP (estimates of local experts are even higher) ${ }^{42}$.

Thus, the global financial crisis has increased the interest of some CIS countries to take a more active part in integration projects promoted by Russia.

In June 2009 Russia, Belarus and Kazakhstan signed an agreement, which created a Custom Union between these countries. The decision to establish a cus-

\footnotetext{
${ }^{41}$ Harding L., "Russian billionaire drops libel case against Economist", The Guardian. 20090730.

${ }^{42}$ Deutsche Welle, ВВП Таджикистана держится на плечах трудовых мигрантов - пора создавать миграиионное министерство, 200803 24. [Deutsche Welle, GDP of Tajikistan rests on the heels of labor migrants - it is time to create ministry of migration, 2008 03 24] - in Russian.
} 
toms union was finally established in December 2009 at the three heads of state meeting in Almaty ${ }^{43}$.

The Custom Union was originally planned to enter into force from 1 July 2010 (between Russia and Belarus, between all three countries - from 1 July 2011).

However, from the beginning of creation of these base principles of the Customs Union's operation, it became clear that the success of this integration project is not guaranteed and the union certainly will begin to function later than planned. Member States are not always able to effectively deal with conflicts arising from the future functioning of customs union. Russia has not yet been fully determined what the additional financial costs it is willing to bear in the name of the Customs union. According to experts, Russia's annual loses of involvement in the project may reach 16 billion U.S. dollars ${ }^{44}$.

The biggest problems arise between Russia and Belarus. Both countries until summer 2010 didn't manage to reach an agreement on how Russian duties on raw oil export to Belarus will be calculated after the introduction of the Customs Union. If an agreement will not be reached, the Customs Union will be limited only to Russia and Kazakhstan (Russia and Kazakhstan have some problems too - transit of the Kazakhstan energy resources through the territory of Russia, Chinese goods for re-export from Kazakhstan to Russia, etc).

On the other hand, the success of the Customs Union will make it possible to create even deeper regional economic and political integration projects, and perhaps even the "new Soviet Union" project. Such an economic block of countries will have a greater weight in the global economic systems than the Russia alone. Especially if Russia's economic potential will be complemented the relatively developed industry in Belarus and Kazakhstan's natural resources.

Russia is actively developing other integration projects in the CIS. For example Eurasian, at the meeting of member countries of Eurasian Economic Community (EurAsEC) in February 2009, it was agreed to create a joint anti-crisis fund.

From this fund immediate relief credits will be provided the member states of the organization, faced with financial difficulties. So actually this fund is the regional counterpart of the IMF. It is clear that assistance from this fund would be more attractive to countries than credits from IMF or World Bank because of not so strict conditionality.

The total size of the fund - 10 billion U.S. dollars. Of these 7.5 billion. will contributed by Russia, 1 billion. U.S. dollars - by Kazakhstan, 10 million U.S. dollars - by Belarus. Kyrgyzstan and Tajikistan will provide 1 million. U.S. dollars each.

\footnotetext{
${ }^{43}$ Совместное заявление президентов Республики Беларусь, Республики Казахстан и Российской Федераиии, Алматы, 200912 19, http://www.tsouz.ru/news/Documents/presidents_zayava.aspx. [Joint Statement by the Presidents of the Republic of Belarus, Republic of Kazakhstan and the Russian Federation, Almaty, 200912 19] - in Russian.

${ }^{44}$ Радио Свобода, Единое конфликтное пространство, 201001 06, http://www.svobodanews.ru/content/ article/1922649.html [Radio Free Europe, Common conflict zone, 201001 06] - in Russian.
} 
However, although an international agreement on the creation of anticrisis fund the establishment was signed in the summer of 2009, the fund operations didn't get started till the summer of 2010 and its future is uncertain.

The economic crisis has increased opportunities for Russia to use credits to foreign countries as a tool of influence. In other words Russia often provides loans in exchange for a "friendly policy" and "right decisions". For example, in January of 2009 Russia lent to Kyrgyzstan 2 billion. U.S. dollars in exchange for an informal promise to remove U.S. airbase in Manas. Lending to Belarus has been associated with the informal promise to recognize independence of Abkhazia and South Ossetia. In 2009 Russia lent 500 million U.S. dollars to Armenia.

At the same time Moscow "teaches" unfriendly countries by refusing to give them credits. For example, Russia refused to give credit to Ukraine in 2009, when president of Ukraine Viktor Yuschenko often used sharp rhetoric when speaking about bilateral relations. On the other hand in 2010, when Viktor Yanukovich became a president of Ukraine, Russia gladly lent 4 billion U.S. dollars to Kiev.

Summing it up, although Russia managed to achieve a good track record in developing economic integration projects in CIS, the future prospects of this process is not clear. It will largely depend on Russia's own economic situation and political will to share resources with its neighbours in the name of integration.

Especially since 2007-2009, Moscow feels growing competition for influence in CIS from China. This country has far greater financial resources than Russia (in summer 2009 Chinese international reserves exceeded 2 trillion. U.S. dollars) and this country is actively seeking new opportunities to invest abroad $^{45}$. In addition to the traditional Chinese business interests in the Central Asia, it began to develop closer relations with countries such as Belarus and Moldova ${ }^{46}$.

\subsection{Increase of the Protectionism Level in Foreign Trade}

Before the crisis, one of the most neo-liberal aspects of Russia's foreign economic policy was the foreign trade regulation. Since 2000 this policy sector was dominated by the desire to join the World Trade Organization, resulting in a constant reduction of import duties and liberalization of foreign trade regulations in general.

\footnotetext{
${ }^{45}$ Bloomberg news, China's Foreign-Exchange Reserves Surge, Exceeding \$2 Trillion, 20090715. 46 In March 2009 it was announced that Belarus and China agreed to swop national currency reserves. They gave each other the Belarusian ruble and the Chinese yuan respectively for the the total equivalent of 3 billion U.S. dollars. These funds will be included in the foreign exchange reserves and in the future will used in the bilateral trade instead of U.S. dollars or Euros. In summer 2009 it was announced that China will provide preferential 1 billion. U.S. dollar loan for Moldova for 15 years, which will be used for infrastructure projects (Chinese companies will take active part in these projects). Infotag, Кредит в \$1млрд от Китая, 200907 23, http://www.azi.md/ru/story/4643 [Infotag, Credit in 1 billion U.S. dollars from China, 200907 23].
} 
The situation has changed substantially after the beginning of the economic crisis. From 1 January 2009 import duties on the second-hand cars were significantly increased. In 2009 there were increased customs duties and nontariff restrictions on certain food products and other goods. A serious drop of the industrial production volume made customs duties and other protection measures of domestic market to seem to be the most reliable option to protect local producers. Protectionism in this case is seen as a tool for economic modernization and diversification (in this case, protecting the weak growth of local manufacturers from much stronger foreign competitors). In addition, the revenues from higher custom tariffs could be used to lower budget deficit.

However, the clearest signal that neo-liberal in Russian foreign economic policy is getting weaker was a decision to join the WTO together with the Customs Union partners - Belarus and Kazakhstan. This was announced in June $2009^{47}$.

In order to understand the reasons for Moscow's decision, it is worth discussing Russia's accession to the WTO process. Russia began its accession to this organization in 1993. By the middle of 2009 these negotiations were almost completed.

The main reasons for Russia to become WTO member were the following:

- Aim to increase its influence in international economic governance process. Russia currently is the largest state, which is not a WTO member. Therefore, Russia cannot participate in the process of an international trade system reformation.

- Improvement of access to the export markets. Direct benefits of accession to the WTO to the Russia's exports are minimal. WTO rules do not regulate the bulk of Russian exports. Neither the raw materials, nor the weapons, fall into the jurisdiction of the WTO. The real positive effect on the Russian exports, at the best, may reach 5-7 billions U.S. dollars (up to 2 percent of the total Russian export volume). At the same time, accession to the WTO would make a negative impact on many Russian industries, which will face increased competition in the domestic market.

- However, if Russia will successfully diversify its economy and become a producer of competitive production with high value added, WTO membership may become necessary.

- Accession to the WTO as the catalyst for liberal reforms within Russia. Russian leadership, especially proponents of liberalism see accession process as an opportunity to liberalize Russia's economic and legal systems. Thus accession to the WTO would carry out a similar role as that of the EU accession of Central and Eastern European countries. Such economic liberalization "from the top" could stimulate successful

${ }^{47}$ RIA Novosti, Russia, Belarus, Kazakhstan seek to join WTO as customs bloc, 20090609. 
development of Russian economy. For example, the head of public corporation "Rosnano" A. Chubais expresses the opinion that the WTO accession would add 1-2 percent of GDP growth annually ${ }^{48}$.

It is clear that the accession to the WTO was project of a neo-liberal part of the Russian ruling elite, which relied on the fact that Russia's success in the international economy will be achieved under the general rules of play.

The decision to join together with Belarus and Kazakhstan, in fact, means that Russia at least in the short term, refuses to access to the WTO. While the WTO rules do not prohibit this organization to be joined in groups of countries, but such a case would be the first in the history. Accession of such different countries with diversify the foreign trade structure and the different domestic economic regulation would require not only very complex negotiations with existing WTO members, but also a number of coordination between "joining partners".

Summing it up, the Russian decision to delay accession to WTO could be explained by:

- First, accession to WTO could potentially be an obstacle to the creation of the Customs Union (for example, Russia would be member of WTO, Belarus - not a member of this organization).

- Secondly, freezing the WTO expands the level of freedom in implementation of protectionist measures and increases the overall independence of Russia's economic policy.

- Thirdly, a reformation process of international trade within the framework of the WTO is halted due to conflicts between member-states. It is likely that Moscow no longer thinks that the WTO membership could significantly increase its influence on the development of agenda for reformation of global economy.

On the other hand such Kremlin decision could be explained as a tactical move, which aim is to strengthen its negotation position in the WTO accession proccess. This version is supported by the Russia's leaders declarations at the end of 2009 - beginning of 2010, that Moscow is still planing to join WTO as soon as possible.

This will show real Moscow's priorities: what is more important - Customs union or accesion to WTO?

\footnotetext{
${ }^{48}$ Росбалт, Чубайс призвал защитить российского товаропотроизводителя перед ВТО, 20090604. [Rosbalt, Chubais called upon to defend Russian producers in WTO accession process, 200906 04.] - in Russian.
} 


\section{Conclusions}

The assessment of Russia's foreign economic policy during the crisis shows that the Kremlin understands this downturn as an opportunity period. In Moscow's opinion, the world economic system after the crisis will not be the same as before, therefore it is needed to secure an as influential as possible position in that coming new world economic order. The new system will be characterized, in its view, by the significant decrease of influence of the West, and the rise of influence of a new (including Russia) economic powers.

Moscow aims to be one of the major players in the transformation process of global financial system. To create a base for such aspirations, Russia aims to build a strong economic power centre. For that purpose, Russia plans of deep economic modernization are declared. Another important component of this strategy are - aims to create an international financial centre in Russia. Finally, but not the last component of a strong power centre building are the - economic integration projects in CIS, which have got new stimulus during the economic crisis.

However, although the majority of Russia's actions in order to benefit from global economic crisis are targeted and have their own logic, this country is still unable to achieve any greater successes. Moscow's proposals on the international financial system transformation are ignored by other major players; creation of international financial centre is much slower than Kremlin wants it to be, as does economic integration in CIS area. Clearly, the most important reasons for these failures are - Russia's economic weakness. Global financial crisis clearly demonstrated the structural problems of this country economy and the Kremlin's inability to effectively deal with them. Another reason for Russia's failures is lack of political will to achieve positive changes in domestic and foreign economic policy.

It is clear that if Russia will fail to resolve its deep economic problems, it may be necessary to take care not to how to achieve the ambitious global goals, but on how to avoid economic disaster at home. In such circumstances, a shift to a more pro-western and neo-liberal policy is possible.

January - June 2010 